\title{
Neuronal seipin knockout facilitates $A \beta$-induced neuroinflammation and neurotoxicity via reduction of PPARY in hippocampus of mouse
}

Yun Qian ${ }^{1,3+}$, Jun Yin ${ }^{2+}$, Juan Hong ${ }^{1,2}$, Guoxi Li ${ }^{1,2}$, Baofeng Zhang ${ }^{2}$, George Liư ${ }^{4}$, Qi Wan ${ }^{3^{*}}$ and Ling Chen ${ }^{1,2^{*}}$

\begin{abstract}
Background: A characteristic phenotype of congenital generalized lipodystrophy 2 (CGL2) that is caused by loss-of-function of seipin gene is mental retardation. Seipin is highly expressed in hippocampal pyramidal cells and astrocytes. Neuronal knockout of seipin in mice (seipin-KO mice) reduces the hippocampal peroxisome proliferator-activated receptor gamma (PPARY) level without the loss of pyramidal cells. The down-regulation of PPARY has gained increasing attention in neuroinflammation of Alzheimer's disease (AD). Thus, the present study focused on exploring the influence of seipin depletion on $\beta$-amyloid ( $A \beta$ )-induced neuroinflammation and $A \beta$ neurotoxicity.
\end{abstract}

Methods: Adult male seipin-KO mice were treated with a single intracerebroventricular (i.c.v.) injection of $A \beta_{25-35}$ (1.2 nmol/mouse) or $A \beta_{1-42}(0.1 \mathrm{nmol} /$ mouse), generally a non-neurotoxic dose in wild-type (WT) mice. Spatial cognitive behaviors were assessed by Morris water maze and Y-maze tests, and hippocampal CA1 pyramidal cells and inflammatory responses were examined.

Results: The $A \beta_{25-35 / 1-42}$ injection in the seipin-KO mice caused approximately 30-35\% death of pyramidal cells and production of Hoechst-positive cells with the impairment of spatial memory. In comparison with the WT mice, the number of astrocytes and microglia in the seipin-KO mice had no significant difference, whereas the levels of IL-6 and TNF-a were slightly increased. Similarly, the $A \beta_{25-35 / 1-42}$ injection in the seipin-KO mice rather than the WT mice could stimulate the activation of astrocytes or microglia and further elevated the levels of IL- 6 and TNF-a. Treatment of the seipin-KO mice with the PPARY agonist rosiglitazone (rosi) could prevent A $\beta_{25-35 / 1-42}$-induced neuroinflammation and neurotoxicity, which was blocked by the PPARY antagonist GW9962. In the seipin-KO mice, the level of glycogen synthase kinase-3 $\beta$ (GSK3 $\beta$ ) phosphorylation at Tyr216 was elevated, while at Ser9, it was reduced compared to the WT mice, which were corrected by the rosi treatment but were unaffected by the $A \beta_{25-35}$ injection.

Conclusions: Seipin deficiency in astrocytes increases GSK3 $\beta$ activity and levels of IL-6 and TNF-a through reducing

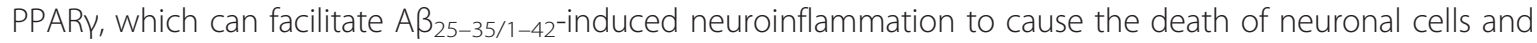
cognitive deficits.

Keywords: Seipin, $\beta$-amyloid (Aß), Neuroinflammation, Peroxisome proliferator-activated receptor gamma (PPARY), Glycogen synthase kinase-3 (GSK3)

\footnotetext{
* Correspondence: lingchen@njmu.edu.cn; qi_wan@126.com

${ }^{\dagger}$ Equal contributors

'State Key Laboratory of Reproductive Medicine, Hanzhong Road 140,

Nanjing 210029, China

${ }^{3}$ Department of Neurology, First Affiliated Hospital of Nanjing Medical

University, Guangzhou Road 300, Nanjing 210029, China

Full list of author information is available at the end of the article
} 


\section{Background}

Congenital generalized lipodystrophy (CGL) is an autosomal recessive disorder that is characterized by a neartotal loss of adipose tissue [1]. Genome-wide linkage analysis has identified two loci related to CGL, i.e., CGL1 mutations in the 1-acylglycerol-3-phosphate O-acyl transferase 2 (AGPAT2) gene and CGL2 mutations in the Berardinelli-Seip congenital lipodystrophy 2 (BSCL2) gene that encodes seipin [2]. CGL2 patients with loss-offunction mutations in the seipin gene exhibit much higher rates of mental retardation than CGL1 patients $[3,4]$. Seipin is highly expressed in the neuronal cells of the cortex, cerebellum, hippocampus, and hypothalamus $[5,6]$. The seipin knockout in rats or mice causes spatial cognitive deficits through the synaptic dysfunction in hippocampal CA1 regions without loss of pyramidal cells $[5,7]$.

Seipin, an exclusive endoplasmic reticulum-residing $\mathrm{N}$-glycosylated protein, can affect the generation of peroxisome proliferator-activated receptor gamma (PPAR $\gamma$ ) [8]. The level of PPAR $\gamma$ is reduced in the embryonic fibroblasts of seipin-deficient mice [9]. We have recently reported that the neuronal knockout of seipin in mice (seipin-KO mice) reduces the expression of the hippocampal PPAR $\gamma[7,10,11]$. The PPAR $\gamma$ is expressed in astrocytes and microglia and exerts an anti-inflammatory effect [12]. PPAR $\gamma$ agonists can inhibit the activations of microglia and astrocytes [13] and reduce the production of pro-inflammatory cytokines [14]. PPAR $\gamma$ deficiency has been reported to increase the neuroinflammation in allergic encephalomyelitis [15] and multiple sclerosis [16]. The levels of pro-inflammatory cytokines, such as tumor necrosis factor- $\alpha$ (TNF- $\alpha$ ), interleukin-6 (IL-6), are elevated in Alzheimer's disease (AD) brains [17]. The activation of PPAR $\gamma$ can enhance the cognitive reserve in humans with $\mathrm{AD}$ and in mouse model for AD amyloidosis [18]. The activation of PPARy can improve hippocampus-dependent cognitive deficits in AD mouse models [19]. The PPAR $\gamma$ activation has been recently shown to mitigate the neuronal inflammation in chronic and acute neurological insults [20]. The PPAR $\gamma$ has received increasing attention in AD due to its anti-inflammatory function [21]. The hippocampal astrocytes express the seipin protein [10]. Thus, it should be interesting to examine whether seipin deficiency in astrocytes through reducing PPAR $\gamma$ affects $A \beta$-induced neuroinflammation and neurotoxicity.

The beneficial effects of PPAR $\gamma$ ligands potentially involve the suppression of signal transducer and activator of transcription (STAT) [22]. Li et al. have reported the elevation of STAT3 activity in the hippocampus of seipin-KO mice [10]. The STAT family of transcription factors has a central role in inflammatory reactions through regulating the expressions of multiple cytokines. In addition, the activation of STAT3 is known to be crucial for the differentiation of astrocytes [23]. Adult
seipin-KO mice showed an increase in the astrocytic differentiation of progenitor cells in the hippocampal dentate gyrus, which can be corrected by the activation of PPAR $\gamma$ [10]. The STAT3 activation is highly dependent on the phosphorylation of glycogen synthase kinase-3 (GSK3) [24]. GSK3 is a constitutively active Ser/Thr kinase consisting of GSK3 $\alpha$ and GSK3 $\beta$ isoforms. GSK3 $\beta$ has been identified as a strong promoter of pro-inflammatory cytokines, including TNF- $\alpha$ and IL-6 [25, 26].

Among the $A \beta$ fragments, a peptide bearing 11 amino acids $(25-35)\left(A \beta_{25-35}\right)$ is the shortest fragment of $A \beta$ that is processed in vivo by brain proteases [27]. This peptide retains the ability to self-aggregate and elicits essentially the same toxicity as the full-length peptide despite lacking the hydrophobic $\mathrm{C}$ terminal sequence of five amino acids that is present in $A \beta_{1-40}$ [28]. In this study, we treated the adult male seipin-KO mice with a single i.c.v. injection of $A \beta_{25-35}$ at a non-neurotoxic dose in control mice $[29,30]$, and then observed the $A \beta_{25-35}$ neurotoxicity (the death of the hippocampal pyramidal cells) and $\mathrm{A} \beta_{25-35}$-induced neuroinflammation (the activation of astrocytes and microglia, the levels of IL-6 and TNF- $\alpha$ ). To test the involvement of reduced PPAR $\gamma$ by seipin deficiency, we investigated the effects of the PPAR $\gamma$ agonist and the PPAR $\gamma$ antagonist on $A \beta_{25-35}$-induced neuroinflammation and $A \beta_{25-35}$ neurotoxicity in the seipin-KO mice. The results of the present study indicate that seipin deficiency in astrocytes facilitates the $\mathrm{A} \beta_{25-35}$-induced neuroinflammation through reducing PPAR $\gamma$ to elevate GSK3 $\beta$ activity, which causes the death of pyramidal cells leading to the spatial cognitive deficits.

\section{Methods}

\section{Generation of seipin knockout (seipin-KO) mice}

All animal handling procedures followed the guidelines for Laboratory Animal Research of Nanjing Medical University. The use of animals was approved by the Institutional Animal Care and Use Committee of Nanjing Medical University. The mice were maintained in constant environmental conditions (temperature $23 \pm 2{ }^{\circ} \mathrm{C}$, humidity $55 \pm 5 \%$, and a 12:12-h light/dark cycle). The neuronal seipin-KO mice were generated as described elsewhere [11]. The genotypes of the seipin-KO mice were identified by PCR using genomic DNA from their tails. The DNA was amplified with the following primers: 5'-CTTGTC TCAAAGGGGTCT-3' (forward primer for loxP) and 5' TCAACAGAACAGACGCT-3' (reverse primer for loxP); and 5'-GCGGTCTGGCAGTAAAAACTATC-3' (forward primer for nestin-Cre) and 5'-GTGAAACAGCATTG CTGTCACTT-3' (reverse primer for nestin-Cre). All animals received a standard laboratory diet before and after all procedures. In this study, 16-week-old male seipin-KO mice $(n=88)$ and wild-type (WT) mice $(n=56)$ were used at the beginning of all experiments. All mice 
were randomly assigned to one of the following six experimental groups: WT mice $(n=24), \mathrm{A} \beta_{25-35}$-treated WT mice $\left(\mathrm{A} \beta_{25-35}\right.$-mice, $\left.n=16\right), \mathrm{A} \beta_{1-42}$-treated WT mice ( $\mathrm{A} \beta_{1-42}$-mice, $\left.n=16\right)$, seipin-KO mice $(n=32), \mathrm{A} \beta_{25-35^{-}}$ treated seipin- $\mathrm{KO}$ mice $\left(\mathrm{A} \beta_{25-35}-\mathrm{KO}\right.$ mice, $\left.n=40\right)$, and $\mathrm{A} \beta_{1-42}$-treated seipin-KO mice $\left(\mathrm{A} \beta_{1-42}-\mathrm{KO}\right.$ mice, $\left.n=16\right)$. Each experiment was performed by two experimenters who were blinded to the experimental groups. The behavioral tests ( $n=16$ mice for each group) and histological observations ( $n=8$ mice for each group) or Western blot analyses ( $n=8$ mice for each group) were sequentially performed in the same cohorts.

\section{Injection (i.c.v.) of $A \beta_{25-35}$ and $A \beta_{1-42}$}

The $A \beta_{25-35}$ (Sigma, St. Louis, MO, USA) was aggregated by incubation in distilled water $(1 \mathrm{mg} / \mathrm{ml})$ at $37^{\circ} \mathrm{C}$ for 4 days and diluted to the final concentration with saline immediately before the experiment [30]. After this treatment, two types of birefringent fibril-like structures and globular aggregates of $A \beta_{25-35}$ can be observed by light microscopic observation [30]. The $A \beta_{1-42}$ (Sigma, St. Louis, MO, USA) was dissolved in 1,1,1,3,3,3-hexafluoro-2-propanol (HFIP, Sigma-Aldrich) and then flashfreezed in liquid nitrogen and lyophilized to completely remove the solvent [31]. Lyophilized $A \beta_{1-42}$ was dissolved in $100 \mathrm{mM} \mathrm{NaOH}$ at a concentration of $6 \mathrm{mg} / \mathrm{ml}$, aliquoted in $50 \mu \mathrm{l}$ volumes [32]. The mice were anesthetized with ketamine $(100 \mathrm{mg} / \mathrm{kg}$, i.p.) and xylazine $(10 \mathrm{mg} / \mathrm{kg}$, i.p. $)$ [33] and placed in a stereotactic apparatus (Motorized Stereotaxic StereoDrive; Neurostar). The "aggregated" $\mathrm{A} \beta_{25-35}(1.2 \mathrm{nmol} / \mathrm{mouse}$ at $2 \mu \mathrm{l})$ or the $\mathrm{A} \beta_{1-42}(0.1 \mathrm{nmol} /$ $2 \mu \mathrm{l}$ in $0.1 \mathrm{M}$ phosphate-buffered saline) was injected into the ventricles $(0.3 \mathrm{~mm}$ posterior, $1.0 \mathrm{~mm}$ lateral, and $2.5 \mathrm{~mm}$ ventral to the bregma) using a stepper-motorized micro-syringe at a rate of $0.3 \mu \mathrm{l} / \mathrm{min}$ [34]. The injection site was confirmed by the injection of Indian ink in the preliminary experiments. The mice infused with the same volume of vehicle served as the control group.

\section{Drug administration}

The PPAR $\gamma$ agonist rosiglitazone (rosi; Enzo, Farmingdale, NY) and the PPAR $\gamma$ antagonist GW9962 (Sigma, St. Louis, MO, USA) were dissolved in dimethyl sulfoxide (DMSO) and then diluted in $0.9 \%$ saline to a final concentration of $0.5 \%$ DMSO. The oral administration (p.o.) of rosi was given daily at a dose of $5 \mathrm{mg} / \mathrm{kg}$ [7]. The GW9962 (1 mg/ $\mathrm{kg} /$ day) was injected intraperitoneally (i.p.) [35].

\section{Behavioral examination}

The behavioral performances on days 5-14 after $\mathrm{A} \beta_{25-35}$ injection were captured via video recording (Winfast PVR; Leadtek Research, Fremont, CA) and analyzed using TopScan Lite 2.0 (Clever Sys., Reston, VA). Morris water maze task: The water maze task was consecutively performed to examine the spatial memory [29]. A pool (diameter $=120 \mathrm{~cm}$ ) made of black-colored plastic was prepared. The water temperature was maintained at 20 $\pm 1{ }^{\circ} \mathrm{C}$ with a bath heater that was used before the sessions. On days 1-2 of training, a cylindrical blackcolored platform (diameter $=7 \mathrm{~cm}$ ) was placed $0.5 \mathrm{~cm}$ above the surface of the water. A mouse was randomly released into one of the four different quadrants and allowed to swim for $90 \mathrm{~s}$. The latency to reach the visible platform was measured. On days 3-7 of the training, the platform was moved to the opposite quadrant of the previously visible platform and submerged $1 \mathrm{~cm}$ below the surface of the water. Four trials were conducted each day with an intertrial interval of $30 \mathrm{~min}$. The average swimming speeds $(\mathrm{m} / \mathrm{s})$ and latencies $(\mathrm{s})$ to reach the platform were scored for all trials. If the mouse was unable to reach the platform within $90 \mathrm{~s}$, the experimenters gently assisted it onto the platform and allowed it to remain there for $15 \mathrm{~s}$. Each mouse began in one of the four quadrants, which was selected in a random manner. On day 8 of the training, a probe trial was performed by removing the platform. The mouse was released from the opposite quadrant relative to the previous location of the platform and allowed to swim for $90 \mathrm{~s}$. The percentages of swimming time spent in the target quadrant, opposite quadrant, and right and left adjacent quadrants were determined. Y-maze task: Spatial working memory performance was assessed by recording spontaneous alternation behavior in a Y-maze [30]. A Y-maze task was performed $48 \mathrm{~h}$ after the probe trial task. The Y-maze was constructed of black-painted wood. Each arm was $40-\mathrm{cm}$ long, $13-\mathrm{cm}$ high, $3-\mathrm{cm}$ wide at the bottom, and $10-\mathrm{cm}$ wide at the top, and the arms converged at equal angles. Each mouse was placed at the end of one arm and allowed to move freely through the maze during an 8-min session. The series of arm entries were recorded visually, and arm entries were considered to be completed when the hind paws of the mouse were completely placed in the arm. Alternations were defined as successive entries into the three arms on overlapping triplet sets. The percentage of alternations was calculated as the ratio of actual to possible alternations (defined as the total number of arm entries minus two). The scorers were blinded to the treatment groups.

\section{Histological examination}

The mice were anesthetized with chloral hydrate ( $400 \mathrm{mg} / \mathrm{kg}$, i.p.) and perfused with $4 \%$ paraformaldehyde. The brains were removed and immersed in $4 \%$ paraformaldehyde at $4{ }^{\circ} \mathrm{C}$ overnight.

Toluidine blue staining: The brains were processed for paraffin embedding, and coronal sections $(5 \mu \mathrm{m})$ were cut. The pyramidal cells in the hippocampal CA1 region were identified using a conventional light microscope 
(Olympus DP70, Tokyo, Japan) with a $60 \times$ objective. The healthy pyramidal neurons exhibited round cell bodies with plainly stained nuclei. Stereological counting CA1 pyramidal cells: The brains were transferred into $30 \%$ sucrose. After gradient dehydration, the coronal sections of the hippocampus $(40 \mu \mathrm{m})$ were cut with a freezing microtome (Leica, Nussloch, Germany) and stained with toluidine blue. Every fourth section was obtained for consecutive cell quantification analyses. Stereological cell counting was performed by a stereological system, consisting of a light microscope with a CCD camera (Olympus DP70), a motorized specimen stage for automatic sampling (MicroBrightField, Williston, USA), and a computer running Microbrightfield Stereo Investigator software (Microbrightfield, Williston, VT, USA) [36]. All counts were performed by the same investigator, who was blind to the treatment. The total numbers of healthy pyramidal cells throughout the hippocampal CA1 region were counted using the optical fractionators' method. The section thickness was measured using a dissector height of $10 \mu \mathrm{m}$. The layer of pyramidal cells was defined according to the terminology of Blackstad [37]. The boundary between the CA3 and CA1 subregions was identified by the differential thickness of the cell layers and by the smaller cell somas of the CA1 subregion. The boundary between CA1 and the subiculum was defined as the line separating the contiguous cells of CA1 from the more widely spaced cells of the subiculum.

Hoechst staining: Coronal paraffin sections $(5 \mu \mathrm{m})$ were incubated in Hoechst $33342(1 \mu \mathrm{g} / \mathrm{ml}$, Cell Signaling Technology, Inc., Boston, MA, USA) for 2 min. Quantitative analyses of Hoechst-positive cells: Hoechst-positive $\left(\right.$ Hoechst $^{+}$) cells in hippocampal CA1 region were observed by a conventional light microscope (Olympus DP70, Japan) with $60 \times$ objective and counted. The density of Hoechst ${ }^{+}$ cells was expressed as the number of cells per millimeter length along the pyramidal cells layer.

GFAP and Ibal staining: The hippocampal sections $(40 \mu \mathrm{m})$ were cut using a cryostat. Every fourth section was obtained with a randomly chosen starting section. The free-floating sections were blocked with $3 \%$ normal goat serum for $60 \mathrm{~min}$. Glial fibrillary acidic protein (GFAP) and ionized calcium-binding adapter molecule 1 (Iba1) immuno-staining were performed using the following primary antibodies and incubation at $4{ }^{\circ} \mathrm{C}$ overnight: mouse anti-GFAP antibody (1:500; Millipore, Billerican, MA, USA) and goat polyclonal anti-Iba1 antibody (1:500; Abcam, Cambridge, UK). Then, the sections were incubated in biotin-labeled goat antimouse IgG antibody (1:400; Santa Cruz Biotechnology, Santa Cruz, CA, USA) or biotin-labeled rabbit anti-goat IgG antibody (1:500; Bioworld Technology, Inc., St. Louis Park, MN, USA) for $2 \mathrm{~h}$ at room temperature. Immuno-reactivity was visualized based on the avidin- biotin-horseradish peroxidase complex (ABC Elite; Vector Laboratories, Inc., Burlingame, CA, USA).

Counting GFAP- and Iba1-positive cells in the hippocampal CA1: The GFAP-positive $\left(\mathrm{GFAP}^{+}\right)$cells and Iba1positive $\left(\mathrm{Iba}^{+}\right)$cells in the hippocampal CA1 radiatum layer were counted using a conventional light microscope (Olympus DP70). The radiatum layer was outlined at $\times 5$ magnification. Systematic random sampling was achieved with a uniform sampling grid superimposed randomly over the region. A counting frame was placed in each square of the grid, and the cells were counted within that frame at $\times 40$ magnification. A cell was counted if the nucleus was stained and was (a) in focus, (b) within the counting frame or crossed the green counting frame inclusion line, and (c) within the optical disector. Total estimated cell number per section $=$ number of counted cells $\times(1 / \mathrm{ssf}) \times(1 / \mathrm{asf}) \times(1 / \mathrm{hsf})$, where ssf is the section sampling fraction, asf is the area sampling fraction, and hsf is the height sampling fraction [38]. The densities of $\mathrm{GFAP}^{+}$cells and $\mathrm{Iba}^{+}$cells are expressed as the mean numbers per $\mathrm{mm}^{3}$, which were normalized to the control value obtained from WT mice [39].

Seipin/GFAP or Iba1 double immuno-staining: The coronal sections (5 $\mu \mathrm{m}$ in thickness) were placed in gelatine-coated slides, blocked with $3 \%$ normal goat serum, and then incubated in rabbit anti-seipin antibody (1:200; Abcam) at $4{ }^{\circ} \mathrm{C}$ overnight, which was revealed using CY3labeled anti-rabbit IgG antibody (1:200; Millipore) or FITClabeled anti-rabbit antibody (1:200; Millipore) and mouse monoclonal anti-GFAP antibody (1:200; Millipore) or goat polyclonal anti-Iba1 antibody (1:500; Abcam), which was revealed using FITC-labeled anti-mouse antibody (1:50; Millipore) or CY3-labeled anti-goat IgG antibody (1:200; Millipore). The immune-positive cells/fibers were observed by a confocal laser-scanning microscope (Leica, Heidelberg, Germany).

\section{Western blot analyses}

The mice were decapitated under deep anesthesia with chloral hydrate. The hippocampus was quickly removed and homogenized in a lysis buffer containing $50 \mathrm{mM}$ Tris- $\mathrm{HCl}$ (pH 7.5), $150 \mathrm{mM} \mathrm{NaCl}, 5 \mathrm{mM}$ EDTA, $10 \mathrm{mM}$ $\mathrm{NaF}, 1 \mathrm{mM}$ sodium orthovanadate, 1 \% Triton X-100, $0.5 \%$ sodium deoxycholate, $1 \mathrm{mM}$ phenyl-methylsulfonyl fluoride, and a protease inhibitor cocktail (Complete; Roche, Mannheim, Germany). The protein concentration was determined with a BCA Protein Assay Kit (Pierce Biotechnology, Rockford, IL, USA). The total proteins $(20 \mu \mathrm{g})$ were separated by SDS-poly-acrylamide gel electrophoresis (SDS-PAGE) and transferred to a polyvinylidene difluoride membrane. The membranes were incubated with $5 \%$ nonfat dried milk in Tris-buffered saline containing $0.1 \%$ Tween 20 for $60 \mathrm{~min}$ at room temperature and were then incubated with a mouse 
monoclonal anti-phospho-GSK3 $\beta$ (Tyr216) antibody (1:1000; Cell Signaling Technology), a rabbit monoclonal anti-phospho-GSK3 $\beta$ (Ser9) antibody, and an antiphospho-STAT3 antibody (1:1000; Cell Signaling Technology); a rabbit polyclonal anti-IL-6 antibody (1:1000; Abcam), a mouse monoclonal anti-TNF- $\alpha$ antibody and a PPAR $\gamma$ antibody (1:200; Santa Cruz Biotechnology); or a mouse monoclonal anti- $\beta$-actin antibody (1:1000; Cell Signaling Technology) and a rabbit monoclonal anti-GAPDH antibody (1:1000; Cell Signaling Technology) at $4{ }^{\circ} \mathrm{C}$ overnight. The membranes were then incubated with HRPlabeled secondary antibodies (1:10,000; Millipore). The blots were stripped by incubation in a stripping buffer (Restore, Pierce) for $5 \mathrm{~min}$, incubated with rabbit polyclonal antibodies for GSK3 $\beta$ or STAT3 (1:1000; Cell Signaling Technology) and developed using an ECL Detection Kit (Millipore). The Western blot bands were scanned and analyzed with an image analysis software package (Image); NIH Image, Bethesda, MD, USA).

\section{Data analysis/statistics}

The data were retrieved and processed with the Microcal Origin 8.0 software. The group data are expressed as the means \pm standard errors, and significance was tested with Student's $t$ tests or ANOVAs with or without repeated measures, followed by Bonferroni post hoc analysis for multiple comparisons. The results of the Morris water maze test were analyzed using repeated-measures ANOVA. The statistical analyses were performed using Stata 7 software (STATA Corporation, College Station, TX, USA). Differences were considered statistically significant at $P<0.05$.

\section{Results}

\section{Seipin deficiency enhances $A \beta_{25-35}$-induced cognitive} deficits

Spatial memory was examined using place learning in a Morris water maze task from day 5 after the injection (i.c.v.) of $A \beta_{25-35}$. The mean latency required to find the visible platform on days $1-2$ of training and the subsequent escape latencies to reach the hidden platform on days 3-7 of training are illustrated in Fig. 1a. First, the latency to reach the visible platform was not affected by genotype $\left(F_{(1,60)}=0.179, P=0.674\right), \mathrm{A} \beta_{25-35}$ injection $\left.\left(F_{(1,} 60\right)=0.054, P=0.818\right)$, or the genotype $\times \mathrm{A} \beta_{25-35}$ interaction $\left.\left(F_{(1,} 60\right)=3.159, \quad P=0.081\right)$. Subsequently, repeated-measures ANOVA revealed that the escape latency to reach the hidden platform progressively decreased with training days in all groups $\left(F_{(4,} 240\right)=$ 71.948, $P<0.001)$, and this effect was influenced by genotype $\left(F_{(1,60)}=190.133, P<0.001\right), \mathrm{A} \beta_{25-35}\left(F_{(1,60)}=\right.$ 39.457, $P<0.001)$, and the genotype $\times \mathrm{A} \beta_{25-35}$ interaction $\left(F_{(1,60)}=36.701, P<0.001\right)$. The seipin-KO mice required longer times to reach the hidden platform on days 5-7 of training than did the WT mice $(P<0.01)$. Furthermore, the $\mathrm{A} \beta_{25-35}$-injected ( $1.2 \mathrm{nmol} /$ mouse) seipin-KO mice exhibited a significantly increased escape latency to the hidden platform $\left(\mathrm{A} \beta_{25-35}-\mathrm{KO}\right.$ mice, $P<$ 0.01 ) compared with the seipin-KO mice, but this effect was not observed in the $A \beta_{25-35}$-injected WT mice (A $\beta_{25-35}$-mice, $P>0.05$ ) relative to the non-injected WT mice. However, the mean swimming speeds during the visible platform and hidden platform tests exhibited by $\mathrm{A} \beta_{25-35}$-mice $(0.26 \pm 0.01 \mathrm{~m} / \mathrm{s}, P>0.05)$, seipin-KO mice $(0.27 \pm 0.03 \mathrm{~m} / \mathrm{s}, P>0.05)$, and $\mathrm{A} \beta_{25-35}-\mathrm{KO}$ mice $(0.27 \pm$ $0.04 \mathrm{~m} / \mathrm{s}, P>0.05)$ were not significantly different from those of the WT mice $(0.26 \pm 0.03 \mathrm{~m} / \mathrm{s})$.

A probe test was performed $24 \mathrm{~h}$ after the hidden platform test to measure the strength of the memory trace. The swimming times spent in the target quadrant, opposite quadrant, and right and left adjacent quadrants are showed in Fig. 1b. The main effect of genotype $\left(F_{(1,}\right.$ $\left.{ }_{60)}=74.061, P<0.001\right)$ and $\mathrm{A} \beta_{25-35}\left(F_{(1,60)}=11.813, P=\right.$ $0.001)$ were that the seipin-KO mice spent less swimming time in the target quadrant than the WT mice $(P$ $<0.01)$. Furthermore, there was a significant interaction of genotype $\times \mathrm{A} \beta_{25-35}\left(F_{(1,60)}=13.716, P<0.001\right)$. Notably, the swimming time in the target quadrant of the $\mathrm{A} \beta_{25-35} \mathrm{KO}$ mice was shorter than that of the seipin-KO mice $(P<0.01)$, whereas the $\mathrm{A} \beta_{25-35}-\mathrm{WT}$ mice exhibited no significant difference compared with the WT mice $(P>0.05)$.

Spatial working memory performance was assessed with a Y-maze task. There was a main effect of genotype on the alternation ratio $\left(F_{(1,}, 60\right)=18.472, P<0.001$; Fig. 1c), but no effect on the number of arm entries was observed $\left(F_{(1,60)}=0.165, P=0.686\right.$; Fig. $\left.1 \mathrm{~d}\right)$. The alternation ratio of the seipin-KO mice was reduced compared to that of the WT mice $(P<0.05)$. Additionally, there was a significant interaction of genotype $\times A \beta_{25-35}$ for the alternation ratio $\left(F_{(1,60)}=7.214, P=0.009\right)$. Notably, $\mathrm{A} \beta_{25-35}-\mathrm{KO}$ mice exhibited a significant reduction in the alternation ratio compared with the seipin-KO mice $(P$ $<0.05)$.

\section{Activation of PPAR $\gamma$ prevents $A \beta_{25-35}$-induced cognitive deficits in seipin-KO mice}

The level of hippocampal PPAR $\gamma$ exhibited a main effect of genotype $\left(F_{(1,28)}=12.778, \mathrm{P}<0.001\right.$; Fig. $\left.2 \mathrm{a}\right)$ but no effect of $\mathrm{A} \beta_{25-35}\left(F_{(1,28)}=0.037, \mathrm{P}=0.848\right)$ or genotype $\times \mathrm{A} \beta_{25-35}$ interaction $\left(F_{(1,28)}=0.374, \mathrm{P}=0.546\right)$. Compared with the WT mice, the level of hippocampal PPARY was remarkably reduced in the seipin-KO mice $(P<0.05)$ but was not significantly different compared with that in the $\mathrm{A} \beta_{25-35}-\mathrm{KO}$ mice $(P>0.05)$.

Consistent with the report by Zhou et al. [7], the treatment of the seipin-KO mice with the PPAR $\gamma$ agonist rosiglitazone (rosi, $5 \mathrm{mg} / \mathrm{kg}$, p.o.) for consecutive 17 days 
A

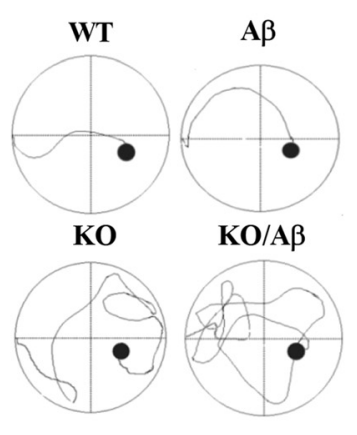

B
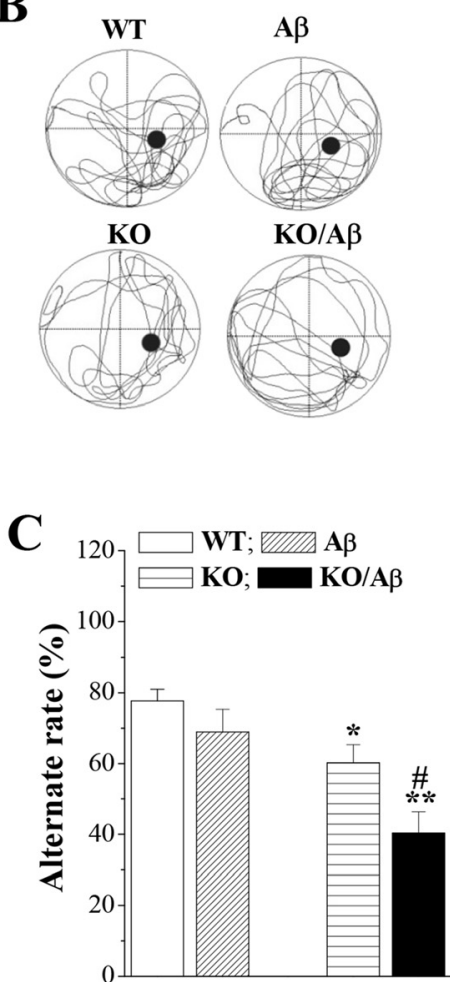
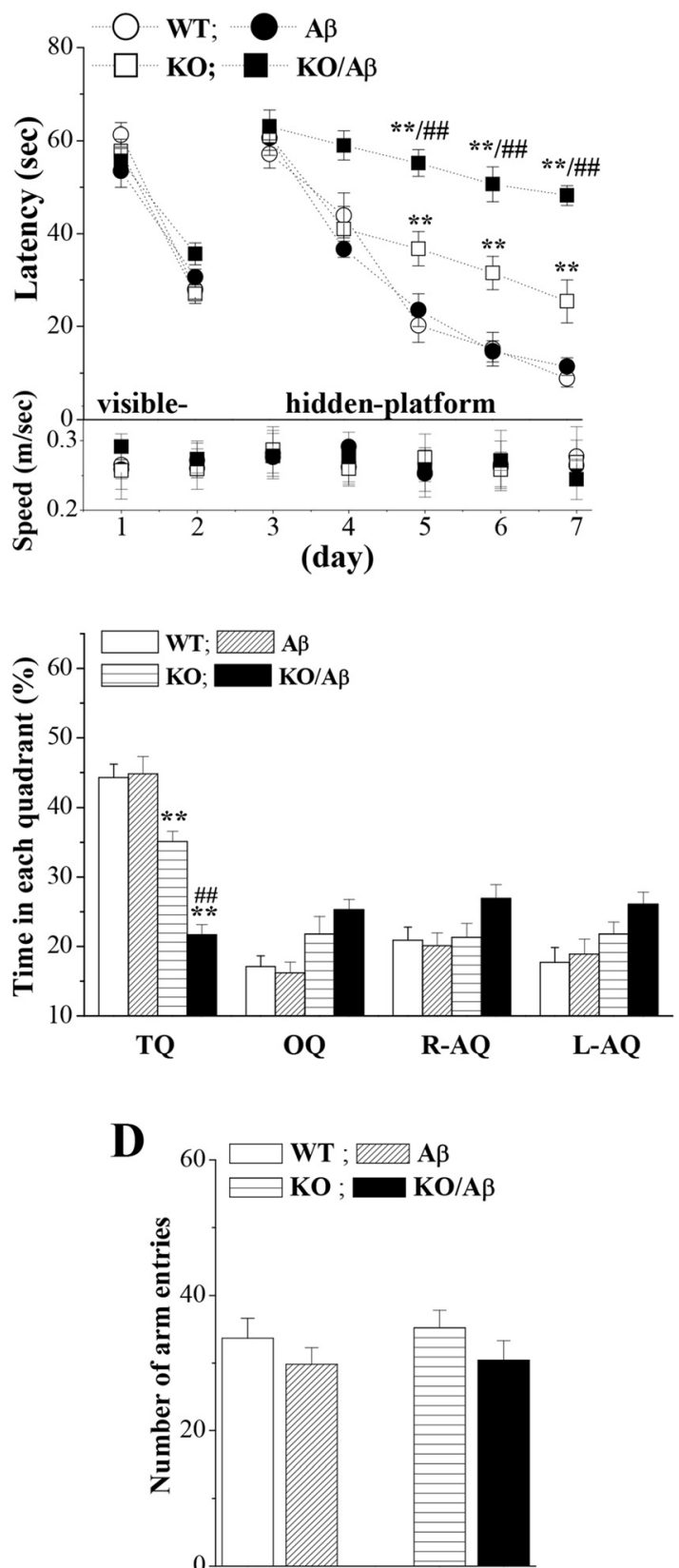

Fig. 1 Seipin deficiency enhances $A \beta_{25-35}$-induced cognitive deficits. a The latencies (s) to reach the visible and hidden platforms (upper panel) and the swimming speeds ( $\mathrm{m} / \mathrm{s}$, bottom panel) of WT mice (WT), $A \beta_{25-35}$ mice (Aß), seipin-KO mice (KO), and $A \beta_{25-35}-K O$ mice $(K O / A \beta)$ in the Morris water maze (MWM) test. The left panels illustrate representative swimming tracks of the mice searching for the underwater platform on day 5 after training. The black dots indicate the position of the hidden platform. ${ }^{* *} P<0.01$ vs. WT mice; ${ }^{\# \#} P<0.01$ vs. seipin-KO mice (repeated-measures ANOVA with Bonferroni's test). b The bars represent the percentages of time spent in the target quadrant (TQ), opposite quadrant (OQ), and right (R) and left ( $L$ ) adjacent quadrants (AQ) of the probe test. The left panels illustrate typical tracks. ${ }^{* *} P<0.01$ vs. WT mice; ${ }^{\# \#} P<0.01$ vs. seipin-KO mice (two-way ANOVA with Bonferroni's test). $\mathbf{c}$, $\mathbf{d}$ The bar graphs display group means in the alternation rate (\%) and the numbers of arm entries ( 8 min) in the $Y$-maze $(Y-M)$ task. ${ }^{*} P<0.05$ and ${ }^{* *} P<0.01$ vs. WT mice; ${ }^{\#} P<0.05$ vs. seipin-KO mice (two-way ANOVA with Bonferroni's test)

corrected the prolongation of escape latencies to reach the hidden platform $(P<0.05, n=16$; Fig. $2 \mathrm{c}-i)$ and the decrease in the swimming time of target quadrant $(P<0.05$, $n=16$; Fig. $2 \mathrm{~d}$ ) and the alternation ratio of Y-maze (KO: $P$
$<0.05, n=8$; $\mathrm{A} \beta_{25-35}$-KO: $P<0.05, n=8$; Fig. $\left.2 \mathrm{e}\right)$. To test the involvement of the reduced PPAR $\gamma$ level in the $A \beta_{25-35-}$ induced cognitive deficits, the rosi treatment was given for consecutive 17 days starting from 2 days before the $A \beta_{25-35}$ 
A

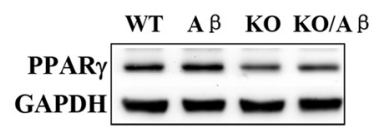

B
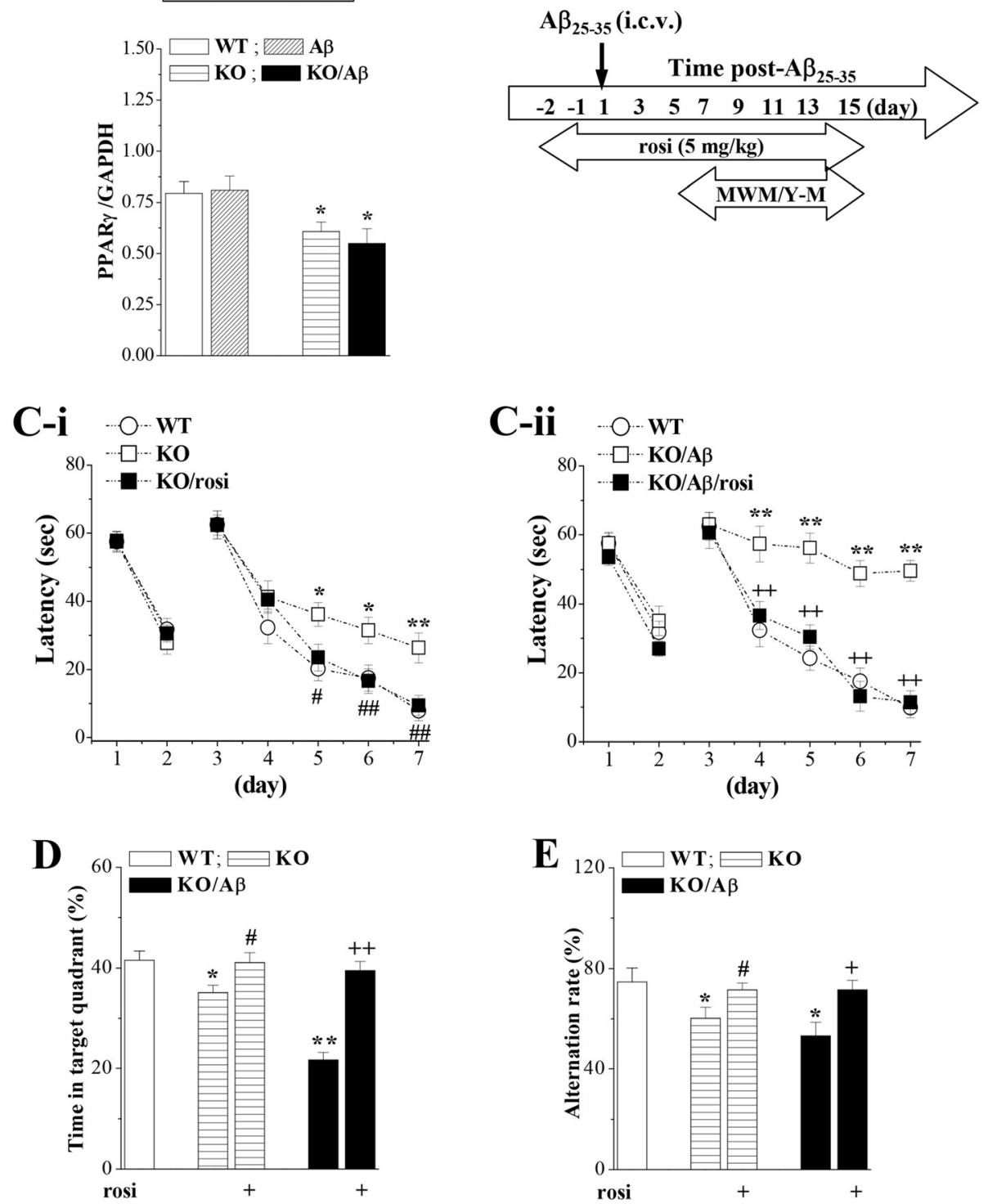

Fig. 2 Activation of PPARy prevents enhanced $A \beta_{25-35}$-induced cognitive deficits by seipin deficiency. a The bars indicate the densitometric values of the hippocampal PPARy protein in WT mice $(W T), A \beta_{25-35}$ mice $(A \beta)$, seipin-KO mice $(K O)$, and $A \beta_{25-35}-K O$ mice $(K O / A \beta)$. ${ }^{*} P<0.05$ vs. WT mice (two-way ANOVA with Bonferroni's test). $\mathbf{b}$ Time chart of the experimental procedure. MWM Morris water maze task, Y-M Y-maze task. $\mathbf{c}-i$ and $\mathbf{c}-i i$ Each point represents the group mean latency $(\mathrm{s})$ to reach the visible and hidden platforms in WT mice, vehicle-treated seipin-KO mice (KO), rosi-treated seipin-KO mice (KO/rosi), $A \beta_{25-35}-\mathrm{KO}$ mice $(K O / A \beta)$, and $A \beta_{25-35}-\mathrm{KO}$ mice $\left(\mathrm{KO} / \mathrm{A} \beta /\right.$ rosi). ${ }^{*} P<0.05$ and ${ }^{* *} P<0.01$ vs. WT mice; ${ }^{*} P<0.05$ and ${ }^{\# \#} P<0.01 \mathrm{vs}$. seipin-KO mice; ${ }^{++} P<0.01$ vs. KO/A $\beta$ mice (repeated-measures ANOVA with Bonferroni's test). $\mathbf{d}$ The bars represent the percentages of time spent in a target quadrant of the probe test. ${ }^{*} P<0.05$ and ${ }^{*} P<0.01$ vs. WT mice; ${ }^{\#} P<0.05$ vs. seipin-KO mice; ${ }^{++} P<0.01$ vs. KO/AB mice (two-way ANOVA with Bonferroni's test). e Bar graph indicates the alternation rates (\%) in the Y-maze task. ${ }^{*} P<0.05$ vs. WT mice; ${ }^{\#} P<0.05$ vs. seipin-KO mice; ${ }^{+} P<0.05$ vs. KO/A $\beta$ mice (two-way ANOVA with Bonferroni's test)

injection (Fig. 2b). In comparison with the vehicle-treated $\mathrm{A} \beta_{25-35} \mathrm{KO}$ mice, the rosi treatment in the $\mathrm{A} \beta_{25-35}-\mathrm{KO}$ mice could perfectly reduce their escape latencies reaching the hidden platform $(P<0.01, n=16$; Fig. $2 c-i i)$ and increase the swimming time in the target quadrant $(P<0.01$, $n=16)$ and alternation ratio in the Y-maze $(P<0.05, n=8)$.
Seipin deficiency enhances $A \beta_{25-35}$-induced death of neuronal cells via PPARy reduction

There was no main effect of genotype $\left(F_{(1,28)}=1.572, P=\right.$ 0.220 ; Fig. 3a) or $\mathrm{A} \beta_{25-35}\left(F_{(1,28)}=2.091, P=0.159\right)$ on the number of pyramidal cells in the hippocampal CA1 region; however, there was a significant genotype $\times \mathrm{A} \beta_{25-35}$ 


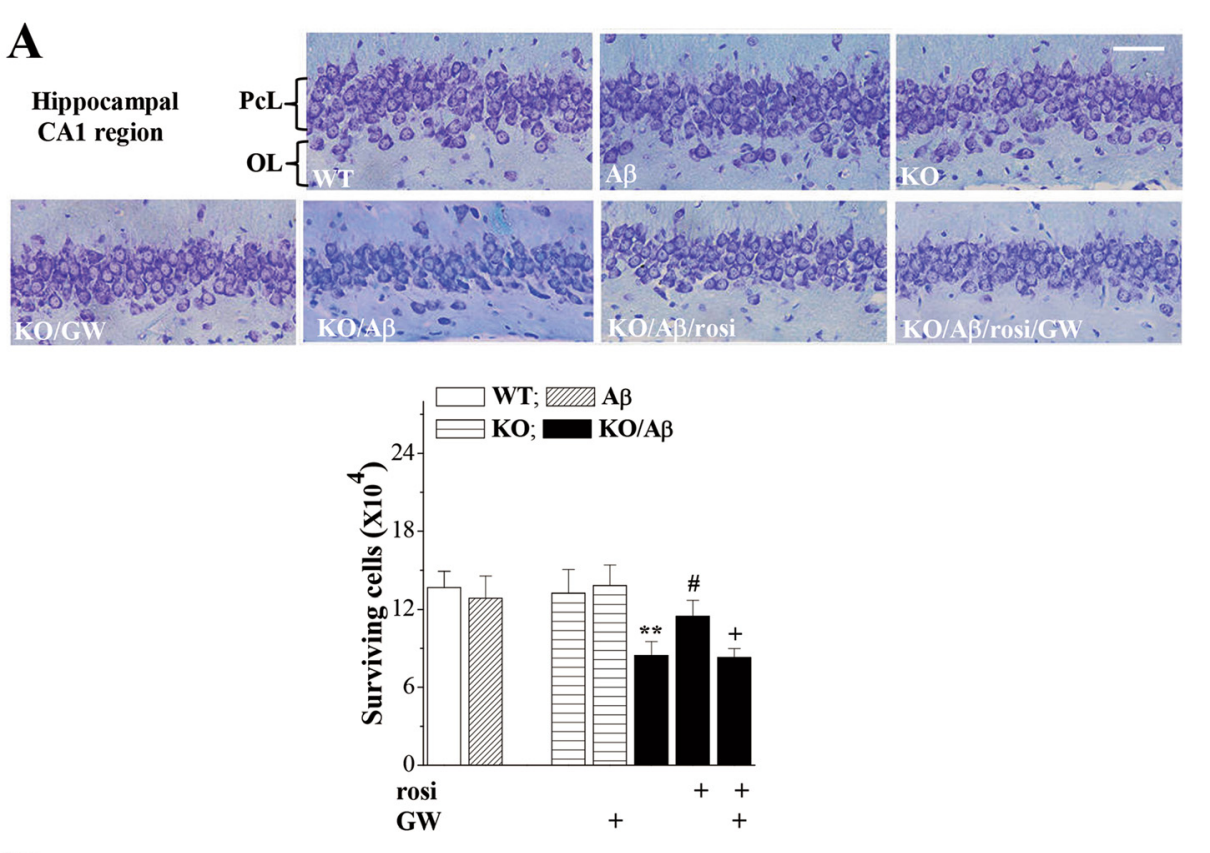

B
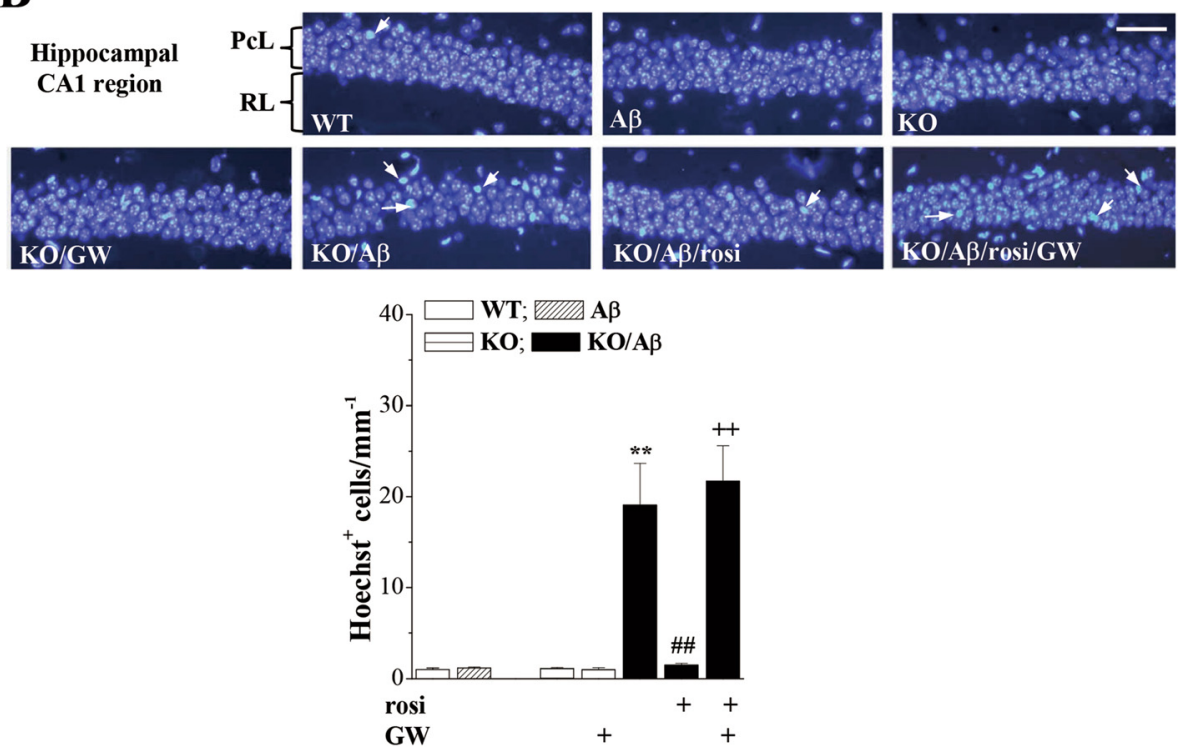

Fig. 3 Activation of PPARY attenuates enhanced $A \beta$ neurotoxicity by seipin deficiency. a Representative images of the hippocampal CA1 regions (5- $\mu \mathrm{m}$ sections stained with toluidine blue) in WT mice (WT), $A \beta_{25-35}$ mice $(A \beta)$, seipin-KO mice $(K O), A \beta_{25-35}-K O$ mice $(K O / A \beta)$, rosi-treated $A \beta_{25-35}-K O$ mice (KO/A $/$ rosi), GW9662-treated seipin-KO mice (KO/GW), and KO/AB/rosi mice (KO/AB/rosi/GW). PCL pyramidal cell layer, OL oriens layer. Scale bars $=50 \mu \mathrm{mm}$.

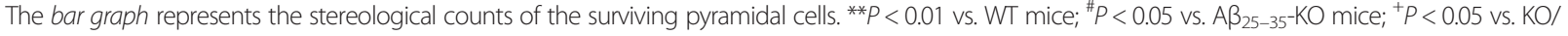
$A \beta /$ rosi mice (three-way ANOVA with Bonferroni's test). $\mathbf{b}$ Representative images of Hoechst staining in the hippocampal CA1 regions. The white arrows indicate the Hoechst ${ }^{+}$cells. PcL: pyramidal cell layer; RL: radiatum layer. Scale bars $=50 \mu \mathrm{m}$. The bars indicate the density of Hoechst ${ }^{+}$cells. ${ }^{* *} P<0.01$ vs. WT mice; ${ }^{\# \#} P<0.01$ vs. $A \beta_{25-35}-\mathrm{KO}$ mice; ${ }^{++} P<0.01$ vs. KO/AB/rosi mice (three-way ANOVA with Bonferroni's test)

interaction $\left(F_{(1,28)}=4.294, \quad P=0.048\right)$. Stereological counts of the surviving pyramidal cells revealed an approximately $35 \%$ loss of pyramidal cells in the $\mathrm{A} \beta_{25-35^{-}} \mathrm{KO}$ mice $(P<0.01)$ and no loss in the $\mathrm{A} \beta_{25-35^{-}}$ mice $(P>0.05)$. As illustrated in Fig. 3b, large numbers of Hoechst-positive $\left(\right.$ Hoechst $^{+}$) cells were observed in the
$\mathrm{A} \beta_{25-35}-\mathrm{KO}$ mice $(P<0.01, n=8)$ but not in the seipin-KO mice $(P>0.05, n=8)$ or the $\mathrm{A} \beta_{25-35}$-mice $(P>0.05, n=8)$. The rosi treatment in the $A \beta_{25-35}-\mathrm{KO}$ mice could attenuate the deaths of pyramidal cells $(P<0.05)$ and the number of Hoechst ${ }^{+}$cells $(P<0.01)$, which were sensitive to the PPAR $\gamma$ antagonist GW9962 (pyramidal cells: $P<0.05$; 
Hoechst $^{+}$cells: $P<0.01$ ). The administration of GW9962 alone in the seipin-KO mice did not affect the survival of pyramidal cells $(P>0.05)$. Similarly, the $A \beta_{1-42}$ injection in the seipin-KO mice rather than the WT mice caused approximately $30 \%$ death of pyramidal cells $(P<0.05, n=8$; Additional file 1: Figure S1), which was prevented by the rosi treatment $(P<0.05, n=8)$.

\section{Seipin deficiency facilitates $A \beta_{25-35}$-induced inflammation via PPARY reduction}

Sequentially, we observed that $\mathrm{GFAP}^{+}$astrocytes expressed highly the seipin protein in the hippocampal CA1 region (upper panels in Fig. 4a) but $\mathrm{Iba}^{+}$microglia did not (bottom panels). The numbers of $\mathrm{Iba}^{+}$cells $(P>0.05, n=8$; Fig. $4 \mathrm{~b})$ or $\mathrm{GFAP}^{+}$cells $(P>0.05, n=8$; Fig. $4 \mathrm{c}$ ) in the seipin-KO mice did not differ from those in the WT mice. Morphological analysis revealed GFAP ${ }^{+}$ stellated-shaped astrocytes with thin processes that denoted a resting phenotype or with thick processes that reflected an activated phenotype [40]. Notably, the numbers of $\mathrm{Iba}^{+}$cells $(P<0.01, n=8)$ and $\mathrm{GFAP}^{+}$activated astrocytes $(P<0.01, n=8)$ were significantly increased in the $\mathrm{A} \beta_{25-35}-\mathrm{KO}$ mice compared with the seipin-KO mice, which were reduced by the rosi treatment $\left(\mathrm{Iba}^{+}\right.$: $P<0.01, n=8$; GFAP $\left.{ }^{+}: P<0.05, n=8\right)$. The inhibitory effects of rosi on the activation of $\mathrm{Iba}^{+}$cells $(P<0.01, n$ $=8)$ and GFAP $^{+}$activated astrocytes $(P<0.05, n=8)$ in the $A \beta_{25-35}-\mathrm{KO}$ mice could be blocked by the PPAR $\gamma$ antagonist GW9962. By contrast, $A \beta_{25-35}$ mice did not show the changes in the numbers of $\mathrm{Iba1}^{+}$cells $(P>$ $0.05, n=8)$ and GFAP $^{+}$cells $(P>0.05, n=8)$ compared to the WT mice. Additionally, the $A \beta_{1-42}$ injection could increase the numbers of $\mathrm{Iba1}^{+}$cells $(P<0.01, n=8$; Additional file 1: Figure S2) and $\mathrm{GFAP}^{+}$activated astrocytes $(P<0.01, n=8)$ in the seipin-KO mice but not in the WT mice, which was sensitive to the rosi treatment (Iba ${ }^{+}$cells: $P<0.01, n=8$; GFAP ${ }^{+}$cells: $P<0.05, n=8$ ).

Further experiment was designed to examine the influence of seipin deficiency on $\mathrm{A} \beta$-induced inflammatory reactions using Western blot. Notably, there were a main effect of genotype for the levels of hippocampal TNF- $\alpha\left(F_{(1,28)}=29.253, P<0.001\right.$; Fig. $\left.4 d\right)$ and IL-6 $\left(F_{(1}\right.$, 28) $=65.073, P<0.001$; Fig. 4e). Additionally, there was a significant genotype $\times \mathrm{A} \beta_{25-35}$ interaction, because the levels of TNF- $\alpha \quad(P<0.01)$ and IL-6 $(P<0.01)$ were higher in the $A \beta_{25-35}-\mathrm{KO}$ mice than those in the seipinKO mice. However, the levels of TNF- $\alpha(P>0.05)$ and IL-6 $(P>0.05)$ exhibited no differences between the WT mice and $A \beta_{25-35}$ mice. Furthermore, the increased TNF- $\alpha$ and IL-6 levels in the seipin-KO mice (TNF- $\alpha$ : $P$ $<0.05$; IL-6: $P<0.01$ ) and the A $\beta_{25-35}$ KO mice (TNF- $\alpha$ : $P<0.01$; IL-6: $P<0.01$ ) were attenuated by the rosi treatment.

\section{Seipin deficiency increases GSK3 $\beta$ activity via PPAR $\gamma$ reduction}

GSK3 $\beta$ has been reported to modulate pro-inflammatory cytokines [26]. GSK3 $\beta$ activity is negatively and positively regulated by phosphorylation at Ser9 and Tyr216, respectively. To explore the mechanisms underlying the seipin deficiency-increased TNF- $\alpha$ and IL-6, we examined the levels of hippocampal GSK3 $\beta$ phosphorylation (phospho-GSK3 $\beta$ ) at Tyr216 and Ser9 [41]. Compared with the WT mice, the level of Tyr216 phospho-GSK3 $\beta$ was elevated $(P<0.01, n=8$; Fig. $5 \mathrm{a})$ and the level of Ser9 phospho-GSK3 $\beta$ was reduced in the seipin-KO mice $(P<0.01, n=8$; Fig. $5 \mathrm{~b})$; and these levels were not affected by the $A \beta_{25-35}$ injection. Interestingly, the rosi treatment in the seipin-KO mice obviously corrected the elevation of Tyr216 phospho-GSK3 $\beta \quad(P<0.01, n=8)$ and the reduction of Ser9 phospho-GSK3 $\beta(P<0.01, n=$ 8). Additionally, the rosi treatment of the WT mice increased Ser9 phospho-GSK3 $\beta(P<0.01, n=8)$ but had no effect on Tyr216 phospho-GSK3 $\beta(P>0.05, n=8)$.

The activation of GSK $3 \beta$ is required to activate tyrosine phosphorylation of STAT3 in astrocytes and microglia [24]. Similarly, the level of hippocampal STAT phosphorylation (phospho-STAT) in the seipin-KO mice was elevated compared with that in the WT mice $(P<$ $0.01, n=8$; Fig. $5 \mathrm{c}$ ). The level of phospho-STAT3 in the seipin-KO mice was further increased by the rosi treatment $(P<0.01, n=8)$ but was not affected by the $\mathrm{A} \beta_{25}$ 35 injection $(P>0.05, n=8)$. Additionally, the rosi treatment increased the level of phospho-STAT3 in the WT mice $(P<0.05, n=8)$.

\section{Discussion}

The present study provides, for the first time, in vivo evidence that the seipin deficiency in astrocytes can facilitate the $A \beta_{25-35 / 1-42}$-induced neuroinflammation to aggravate the $A \beta_{25-35 / 1-42}$ neurotoxicity. This conclusion was deduced mainly from the following observations: (1) seipin was highly expressed in hippocampal pyramidal cells and astrocytes; (2) the seipin deficiency did not alter the number of neuronal cells, astrocytes, and microglia, but the levels of IL-6/TNF- $\alpha$ were higher in the seipin-KO mice than those in WT mice; (3) the injection (i.c.v.) of $\mathrm{A} \beta_{25-35}\left(1.2 \mathrm{nmol} /\right.$ mouse) or $\mathrm{A} \beta_{1-42}$ $(0.1 \mathrm{nmol} / \mathrm{mouse})$ could stimulate the activation of astrocytes and microglia and further increased the expression of IL-6/TNF- $\alpha$ in seipin-KO mice, but not in the WT mice; (4) the injection (i.c.v.) of $A \beta_{25-35}$ or $A \beta_{1-42}$, at the non-neurotoxic doses in WT mice, caused approximately 30-35 \% death of pyramidal cells with a significant increase of apoptotic cells in hippocampal CA1 of the seipin-KO mice leading to the impairment of spatial memory. 

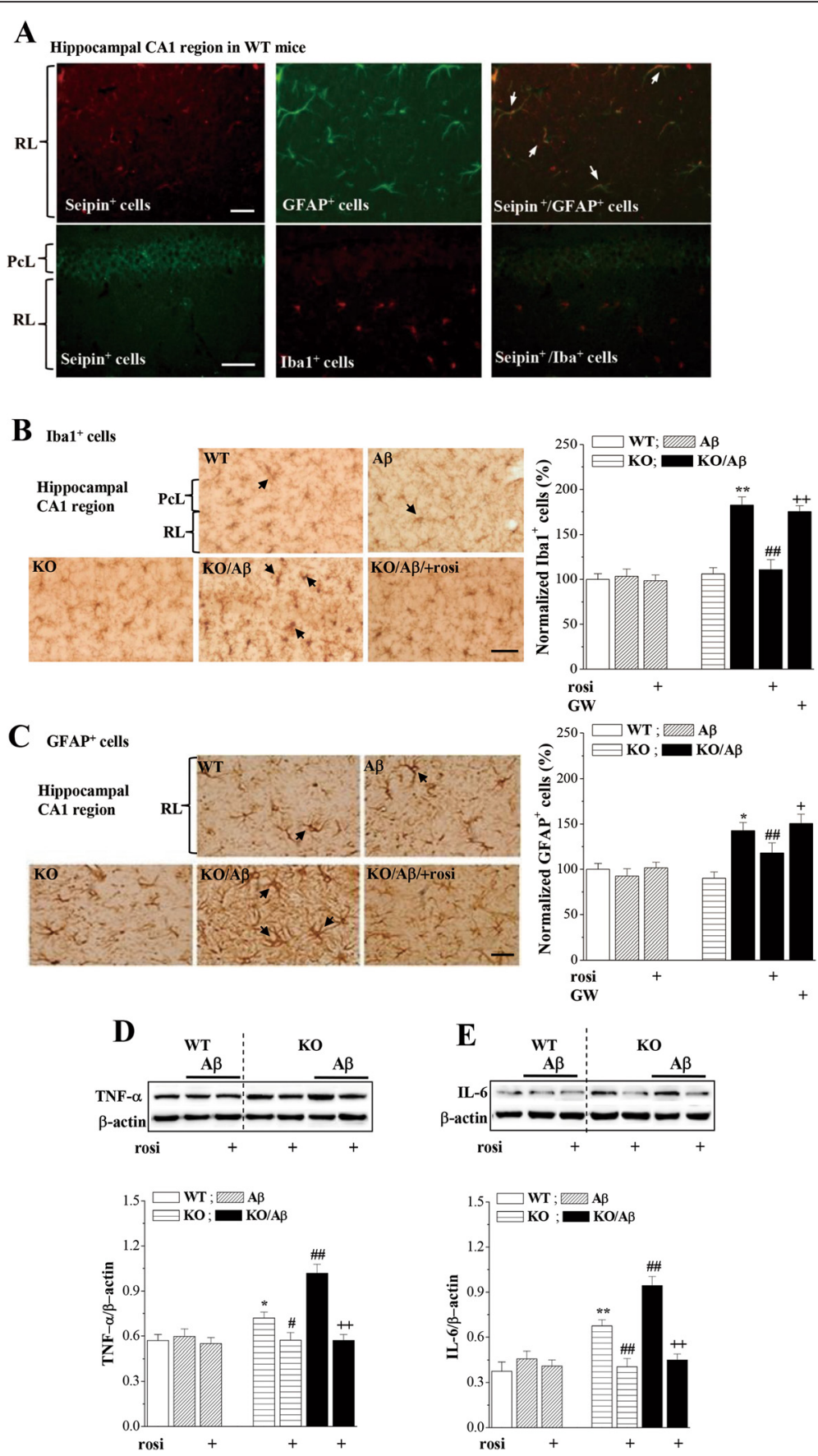

Fig. 4 Activation of PPARy reduces the enhanced Aß-induced inflammation by seipin deficiency. a The upper panel shows representative fluorescence images by seipin (red color, left column) and GFAP (green color, middle column) double immuno-staining in hippocampal CA1 regions of WT mice (scale bar $=50 \mu \mathrm{m}$ ). The white arrows indicate seipin/GFAP-positive cells (yellow color, right column). The bottom panels shows the representative pictures of seipin (green color, left column) and Iba1 (red color, middle column) double immuno-staining in hippocampal CA1 regions of WT mice (scale bar $=50 \mu \mathrm{m})$. PCL pyramidal cell layer, $R L$ radiatum layer. b, c Representative pictures of $\mathrm{Iba}^{+}$cells $(\mathrm{scale}$ bar $=50 \mu \mathrm{m})$ and GFAP ${ }^{+}$cells $(s c a l e ~ b a r=$ $25 \mu \mathrm{m})$ in the hippocampal $C A 1$ regions of $W T$ mice $(W T), A \beta_{25-35}$ mice $(A \beta)$, seipin-KO mice $(K O), A \beta_{25-35}-K O$ mice $(K O / A \beta)$, and rosi-treated $K O / A \beta$

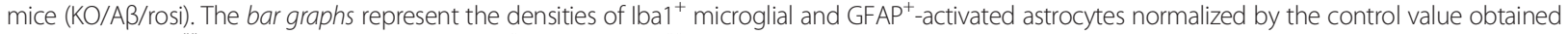
from WT mice. ${ }^{* *} P<0.01$ vs. seipin-KO mice; ${ }^{\#} P<0.05$ and ${ }^{\# \#} P<0.01$ vs. $A \beta_{25-35}-\mathrm{KO}$ mice; ${ }^{+} P<0.05$ and ${ }^{++} P<0.01$ vs. KO/A $/$ rosi mice (three-way ANOVA with Bonferroni's test). d, e Levels of hippocampal TNF-a and IL-1 $\beta$. ${ }^{*} P<0.05$ and ${ }^{* *} P<0.01$ Vs. WT mice; ${ }^{*} P<0.05$ and ${ }^{\# \#} P<0.01$ vs. seipin-KO mice; ${ }^{++} P<0.01$ vs. $A \beta_{25-35}-\mathrm{KO}$ mice (three-way ANOVA with Bonferroni's test) 


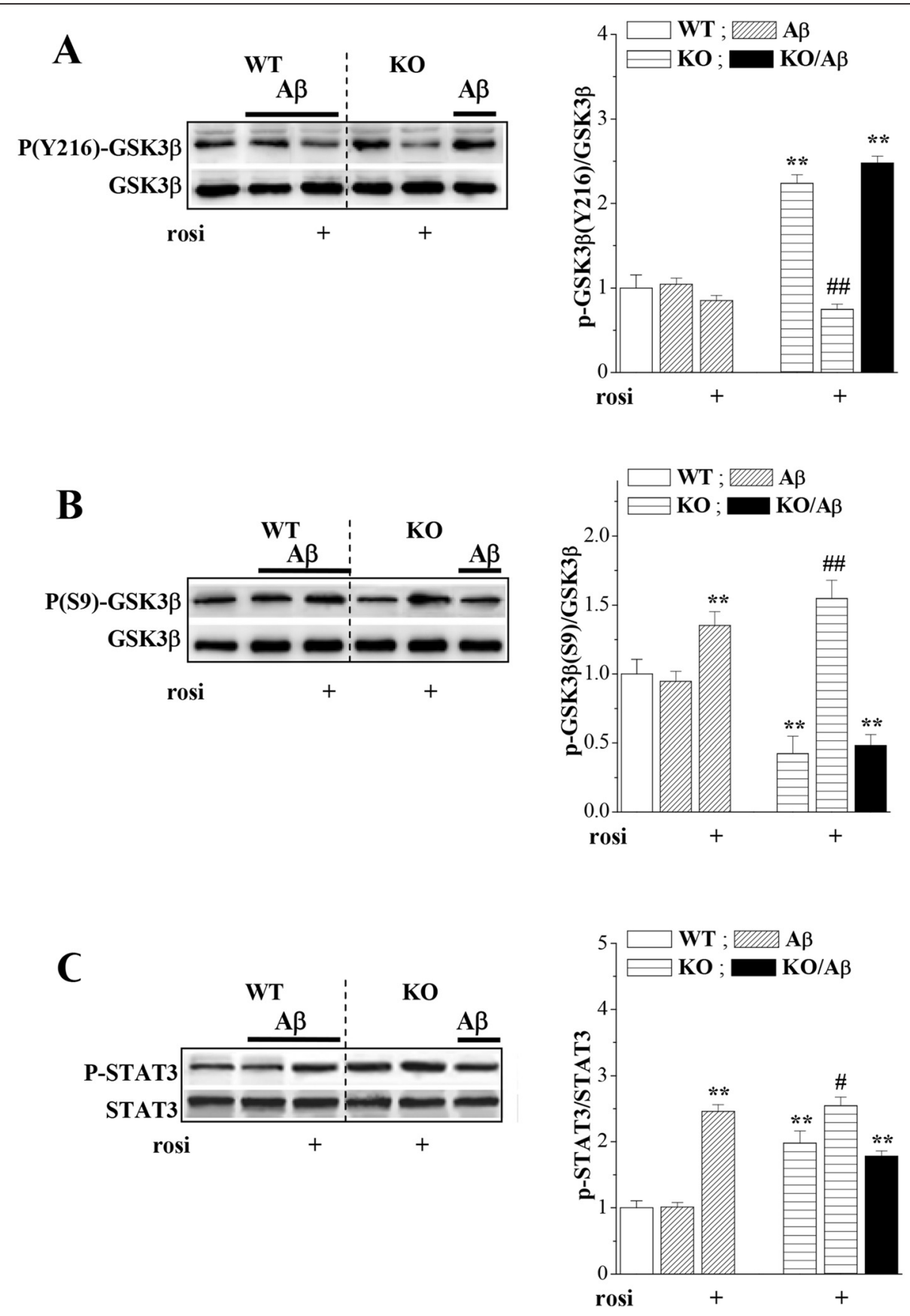

Fig. 5 Activation of PPARY depresses enhanced GSK3 $\beta$ activity by seipin deficiency. a-c Levels of hippocampal Tyr216 phospho-GSK3 3 , Ser9 phospho-GSK3 $\beta$, and phospho-STAT3 in WT mice (WT), A $\beta_{25-35}$ mice (Aß), seipin-KO mice (KO), $A \beta_{25-35}-K O$ mice $(K O / A \beta)$, and rosi-treated $A \beta$ mice and KO/A $\beta$ mice. Levels of Tyr216 phospho-GSK3 $\beta$ and Ser9 phospho-GSK3 $\beta$ were first normalized to the amount of GSK3 $\beta$ protein and subsequently normalized to the basal values in WT mice. ${ }^{* *} P<0.01$ vs. WT mice; ${ }^{\# \#} P<0.01$ vs. A $\beta_{25-35}-K O$ mice (three-way ANOVA). The levels of phospho-STAT3 were normalized to the amount of STAT3 protein and subsequently normalized to the basal values in WT mice. ${ }^{* *} P<0.01$ vs. WT mice; ${ }^{\#} P<0.05$ vs. $\mathrm{A} \beta_{25-35}-\mathrm{KO}$ mice (three-way ANOVA with Bonferroni's test)

\section{Seipin deficiency in astrocytes facilitates} $A \beta$-neuroinflammation via the reduction of PPAR $\gamma$ The treatment of astrocytes and microglia with $A \beta_{1-42}$ can increase the production of IL- 6 and TNF- $\alpha$, which is inhibited by the activation of PPARY [42]. The PPAR $\gamma$ agonists can prevent the overproduction of IL-6 and TNF- $\alpha$ in astrocytes and microglia treated with lipopolysaccharide (LPS) [43]. The injection (i.c.v.) of $\mathrm{A} \beta_{25-35}$ stimulates microglial activation in the brains of $\mathrm{C} 57 \mathrm{BL} /$ 6J mice [44]. The injection (i.c.v.) of $\mathrm{A} \beta_{25-35}(1.2 \mathrm{nmol} /$ 
mouse) or $A \beta_{1-42}(0.1 \mathrm{nmol} /$ mouse $)$ was insufficient to stimulate the activation of astrocytes and microglia or to increase the production of TNF- $\alpha$ or IL- 6 in WT mice. However, this injection (i.c.v.) of $A \beta_{25-35}$ or $A \beta_{1-42}$ in the seipin-KO mice caused the activation of astrocytes and microglia with an obvious increase in the level of TNF- $\alpha$ or IL-6. Interestingly, in particular, the activation of PPAR $\gamma$ in the seipin-KO mice was able to prevent the $A \beta_{25-35 / 1-42}$-induced neuroinflammation. Similarly, PPAR $\gamma$-deficient heterozygous mice develop an exacerbated experimental allergic encephalomyelitis (EAE) in comparison with the wild-type littermates [15]. The exacerbation of EAE by the PPARY antagonists associates with an augmented neural inflammation [16]. Astrocytes and microglia are fundamental cellular targets for the beneficial effects of PPARy ligands [13]. We observed the seipin expression in hippocampal astrocytes. Although the number of astrocytes in the hippocampal CA1 region of the seipin-KO mice did not differ in comparison with the WT mice, the levels of hippocampal TNF- $\alpha$ and IL- 6 in the seipin-KO mice were higher than those in the WT mice. In particular, the elevation of TNF- $\alpha$ or IL-6 in the seipin-KO mice was reduced by the PPARY agonist. Thus, it may be possible that the reduction of PPAR $\gamma$ leads to the overproduction of pro-inflammatory cytokines in the seipin-KO mice, which facilitates the $A \beta_{25-}$ 35/1-42-induced neuroinflammation. Another indirect but important supporting data is that the increased TNF- $\alpha$ and IL-6 in the seipin-KO mice could be corrected by the activation of PPAR $\gamma$. Therefore, the findings give an indication that the seipin deficiency in astrocytes is able to facilitate the $\mathrm{A} \beta$-induced neuroinflammation probably through reducing PPAR $\gamma$ to elevate the levels of TNF- $\alpha$ and IL-6.

\section{Seipin deficiency enhances GSK3 $\beta$ activity to increase pro-inflammatory cytokines}

GSK3 $\beta$ has been identified as a strong promoter of proinflammatory cytokines, including IL- 6 and TNF- $\alpha[25,26]$. The inhibition of GSK3 $\beta$ increases inflammatory tolerance and reduces inflammatory sensitization in the brain [45]. GSK3 $\beta$ inhibition in glial cells reduces pro-inflammatory responses by blocking STAT3 signaling [46]. The inhibition of GSK3 reduces STAT3 activation, IL-6 production, and GFAP up-regulation by LPS-stimulated primary glia [47]. The activation of PPAR $\gamma$ potentially suppresses the activator of STAT [48]. The level of STAT3 phosphorylation was significantly increased in the seipin-KO mice [10]. STAT3 activation is highly dependent on GSK3 $\beta$ in mouse primary astrocytes [24]. Notably, the catalytic activity of GSK3 $\beta$ in seipin-KO mice was enhanced as indicated by the elevation of Tyr216 phospho-GSK3 $\beta$ and the reduction of Ser9 phospho-GSK3 $\beta$. The activation of PPAR $\gamma$ regulates negatively the expressions of GSK3 $\beta$ [49], but the level of GSK3 $\beta$ protein failed to be increased in the seipin-KO mice. Strangely enough, the administration of rosi to the
seipin-KO mice could suppress the increase of GSK3 $\beta$ activity but further enhanced the phosphorylation of STAT3. Therefore, it is indicated that seipin deficiency in astrocytes through reducing PPAR $\gamma$ enhances the GSK3 $\beta$ activity rather than the STAT3 signaling to increase the production of TNF- $\alpha$ and IL- 6 . On the other hand, GSK3 $\beta$ regulates interferon- $\gamma($ IFN- $\gamma$ ) signaling and is involved in IFN- $\gamma$-induced inflammation [50]. Thus, further studies are required to examine whether the GSK3 $\beta$ activity in seipin$\mathrm{KO}$ mice through synergistically facilitating IFN- $\gamma$-induced STAT1 activation increases the production of TNF- $\alpha$ [41].

\section{Seipin deficiency enhances $A \beta$-neurotoxicity via the reduction of PPARY}

A principal finding in this study is that seipin deficiency in hippocampal neuronal cells enhances the $A \beta_{25-35 / 1-42}$ neurotoxicity as indicated by a massive death of pyramidal cells in the seipin-KO mice treated with the $A \beta_{25-35}$ $(1.2 \mathrm{nmol} /$ mouse $)$ or $A \beta_{1-42}(0.1 \mathrm{nmol} /$ mouse $)$, generally non-neurotoxic doses in the WT mice or control mice [29]. The level of the hippocampal PPARY was significantly reduced in the seipin-KO mice. The decline of PPAR $y$ in the seipin-KO mice [11] or the neuronal specific PPAR $\gamma$ knockout in mice [51] did not cause the loss of neuronal cells in the hippocampus. The rosi treatment

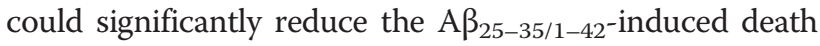
of pyramidal cells in the seipin-KO mice. Activated microglia and reactive astrocytes can produce cytokines, reactive oxygen species, and other neurotoxic substances to cause neuronal apoptosis and other series of pathologic events. The progressive neuroinflammation and neuronal apoptosis in $\mathrm{AD}$ is considered to be a consequence of the $\mathrm{A} \beta$ neurotoxic properties [52, 53]. Our data support the notion that $A \beta_{25-35 / 1-42}$-induced neuroinflammation in the seipin-KO mice causes the death of neuronal cells. Zhao et al. [51] reported that neuronal PPAR $\gamma$ deficiency increased susceptibility to brain damage after cerebral ischemia through suppressing the expressions of $\mathrm{Cu}-\mathrm{Zn}$ superoxide dismutase (SOD1), catalase (CAT), and glutathione S-transferase (GST). However, the levels of hippocampal SOD1, CAT, and GST expression in seipin-KO mice did not differ from WT mice (data not shown). Additionally, Ito et al. reported that mutations (N88S/S90L) of the seipin gene can cause the formation of cytoplasmic inclusions and enhance ubiquitination, which leads to endoplasmic reticulum (ER) stress [54]. However, this idea is not supported because the levels of the ER stress makers $\mathrm{BiP}$ and $\mathrm{CHOP}$ in seipin-KO mice are not increased [11].

\section{Conclusions}

Using the seipin-KO mice with reduction of PPAR $\gamma$, we observed that seipin deficiency elevated the activity of GSK3 $\beta$ to enhance the production of TNF- $\alpha$ and IL- 6 , which in turn triggered and strengthened the $A \beta_{25-35^{-}}$ 
induced inflammatory responses leading to the death of neuronal cells and the spatial cognitive deficits. This is particularly true of neuroinflammation, which contributes to a broad range of neurodegenerative diseases [55]. Although much more work needs to be performed in the future, this is the first report to demonstrate that the expression of seipin in hippocampal astrocytes is required for regulating the inflammatory responses and preventing the neurodegeneration.

\section{Highlights}

(1)Hippocampal GSK3 $\beta$ activity and IL-6/TNF- $\alpha$ were slightly increased in seipin-KO mice.

(2) PPAR $\gamma$ agonist inhibits increased GSK3 $\beta$ activity and IL-6/TNF- $\alpha$ in KO mice.

(3)Low-dose $A \beta_{25-35}$ causes death of pyramidal cells in $\mathrm{KO}$ mice, not in WT mice.

(4) $\mathrm{A} \beta_{25-35}$ activates microglia and astrocytes to increases IL-6/TNF- $\alpha$ in $\mathrm{KO}$ mice.

(5) PPAR $\gamma$ agonist prevents $A \beta_{25-35}$-neuroinflammation and -neurotoxicity in $\mathrm{KO}$ mice.

\section{Additional file}

Additional file 1: Effects of neuronal seipin knockout on $A \beta_{1-42}$-induced neurotoxicity and neuroinflammation. (116 KB)

\section{Abbreviations}

AD, Alzheimer's disease; AGPAT2, 1-acylglycerol-3-phosphate-O-acyl transferase 2; A $\beta$, $\beta$-amyloid; BSCL2, Berardinelli-Seip congenital lipodystrophy 2; CGL, congenital generalized lipodystrophy; GFAP, glial fibrillary acidic protein; GSK3, glycogen synthase kinase-3; i.c.v., intracerebroventricular; Iba $1^{+}$, ionized calcium-binding adaptor molecule 1-positive; IL-6, interleukin-6; PA, phosphatidic acid; PPARY, peroxisome proliferator-activated receptor gamma; seipin-KO mice, seipin knockout mice; STAT, signal transducer and activator of transcription; TNF- $a$, tumor necrosis factor-a

\section{Acknowledgments}

This work was supported by the National 973 Basic Research Program of China (grant number 2014CB943303) and the National Natural Science Foundation of China (grant numbers 31171440, 81361120247, and 81471157) to Chen L.

\section{Availability of data and materials}

We agree to share our data obtained in the study.

\section{Authors' contributions \\ In this study, YQ performed the histological examination of the neurogenesis, Western blot, and RT-PCR analysis. JY participated in the seipin immuno-staining and all statistical analysis. JH, GL, and BZ contributed to the animal care and behavioral examination. GL, QW helped to edit the manuscript. LC carried out the experimental design and finished the manuscript. All authors read and approved the final manuscript.}

\section{Competing interests}

The authors declare that they have no competing interests.

\section{Consent for publication}

Not applicable.
Ethics approval and consent to participate

The use of animals was approved by the Ethic Committee of Nanjing Medical University (2014, No. 153).

\section{Author details}

${ }^{1}$ State Key Laboratory of Reproductive Medicine, Hanzhong Road 140, Nanjing 210029, China. ${ }^{2}$ Department of Physiology, Nanjing Medical University, Hanzhong Road 140, Nanjing 210029, China. ${ }^{3}$ Department of Neurology, First Affiliated Hospital of Nanjing Medical University, Guangzhou Road 300, Nanjing 210029, China. Institute of Cardiovascular Sciences, Peking University and Key Laboratory of Cardiovascular Sciences, China Administration of Education, Beijing 100191, China.

Received: 27 January 2016 Accepted: 24 May 2016

Published online: 10 June 2016

\section{References}

1. Agarwal AK, Garg A. Congenital generalized lipodystrophy: significance of triglyceride biosynthetic pathways. Trends Endocrinol Metab. 2003;14:214-21.

2. Magre J, Delepine M, Khallouf E, Gedde-Dahl Jr T, Van Maldergem L, Sobel E, Papp J, Meier M, Megarbane A, Bachy A, et al. Identification of the gene altered in Berardinelli-Seip congenital lipodystrophy on chromosome 11q13. Nat Genet. 2001;28:365-70.

3. Van Maldergem L, Magre J, Khallouf TE, Gedde-Dahl Jr T, Delepine M, Trygstad O, Seemanova E, Stephenson T, Albott CS, Bonnici F, et al. Genotype-phenotype relationships in Berardinelli-Seip congenital lipodystrophy. J Med Genet. 2002;39:722-33.

4. Rajab A, Khaburi M, Spranger S, Kunze J, Spranger J. Congenital generalized lipodystrophy, mental retardation, deafness, short stature, and slender bones: a newly recognized syndrome? Am J Med Genet A. 2003;121A:271-6.

5. Ebihara C, Ebihara K, Aizawa-Abe M, Mashimo T, Tomita T, Zhao M, Gumbilai $V$, Kusakabe T, Yamamoto Y, Aotani D, et al. Seipin is necessary for normal brain development and spermatogenesis in addition to adipogenesis. Hum Mol Genet. 2015;24:4238-49.

6. Garfield AS, Chan WS, Dennis RJ, Ito D, Heisler LK, Rochford JJ. Neuroanatomical characterisation of the expression of the lipodystrophy and motor-neuropathy gene Bscl2 in adult mouse brain. PLoS One. 2012;7:e45790.

7. Zhou L, Chen T, Li G, Wu C, Wang C, Li L, Sha S, Chen L, Liu G, Chen L. Activation of PPARgamma ameliorates spatial cognitive deficits through restoring expression of AMPA receptors in Seipin knock-out mice. J Neurosci. 2016;36:1242-53.

8. Fei W, Du X, Yang H. Seipin, adipogenesis and lipid droplets. Trends Endocrinol Metab. 2011;22:204-10.

9. Prieur X, Dollet L, Takahashi M, Nemani M, Pillot B, Le May C, Mounier C, Takigawa-Imamura H, Zelenika D, Matsuda F, et al. Thiazolidinediones partially reverse the metabolic disturbances observed in Bscl2/seipindeficient mice. Diabetologia. 2013;56:1813-25.

10. Li G, Zhou L, Zhu Y, Wang C, Sha S, Xian X, Ji Y, Liu G, Chen L. Seipin knockout in mice impairs stem cell proliferation and progenitor cell differentiation in the adult hippocampal dentate gyrus via reduced levels of PPARgamma. Dis Model Mech. 2015;8:1615-24.

11. Zhou L, Yin J, Wang C, Liao J, Liu G, Chen L. Lack of seipin in neurons results in anxiety- and depression-like behaviors via down regulation of PPARgamma. Hum Mol Genet. 2014;23:4094-102.

12. Ho GJ, Drego R, Hakimian E, Masliah E. Mechanisms of cell signaling and inflammation in Alzheimer's disease. Curr Drug Targets Inflamm Allergy. 2005:4:247-56.

13. Landreth G, Jiang Q, Mandrekar S, Heneka M. PPARgamma agonists as therapeutics for the treatment of Alzheimer's disease. Neurotherapeutics. 2008:5:481-9.

14. Heneka MT, Gavrilyuk V, Landreth GE, O'Banion MK, Weinberg G, Feinstein $D L$. Noradrenergic depletion increases inflammatory responses in brain: effects on IkappaB and HSP70 expression. J Neurochem. 2003:85:387-98.

15. Natarajan C, Muthian G, Barak Y, Evans RM, Bright JJ. Peroxisome proliferator-activated receptor-gamma-deficient heterozygous mice develop an exacerbated neural antigen-induced Th1 response and experimental allergic encephalomyelitis. J Immunol. 2003:171:5743-50.

16. Raikwar HP, Muthian G, Rajasingh J, Johnson C, Bright JJ. PPARgamma antagonists exacerbate neural antigen-specific Th1 response and experimental allergic encephalomyelitis. J Neuroimmunol. 2005;167:99-107. 
17. Wang WY, Tan MS, Yu JT, Tan L. Role of pro-inflammatory cytokines released from microglia in Alzheimer's disease. Ann Transl Med. 2015;3:136

18. Jahrling JB, Hernandez CM, Denner L, Dineley KT. PPARgamma recruitment to active ERK during memory consolidation is required for Alzheimer's disease-related cognitive enhancement. J Neurosci. 2014;34:4054-63.

19. Denner LA, Rodriguez-Rivera J, Haidacher SJ, Jahrling JB, Carmical JR, Hernandez CM, Zhao Y, Sadygov RG, Starkey JM, Spratt H, et al. Cognitive enhancement with rosiglitazone links the hippocampal PPARgamma and ERK MAPK signaling pathways. J Neurosci. 2012;32:16725-16735a.

20. Kapadia R, Yi JH, Vemuganti R. Mechanisms of anti-inflammatory and neuroprotective actions of PPAR-gamma agonists. Front Biosci. 2008;13:1813-26.

21. Gasparini L, Ongini E, Wenk G. Non-steroidal anti-inflammatory drugs (NSAIDs) in Alzheimer's disease: old and new mechanisms of action. J Neurochem. 2004;91:521-36.

22. Park EJ, Park SY, Joe EH, Jou I. 15d-PGJ2 and rosiglitazone suppress Janus kinase-STAT inflammatory signaling through induction of suppressor of cytokine signaling 1 (SOCS1) and SOCS3 in glia. J Biol Chem. 2003;278:14747-52.

23. He F, Ge W, Martinowich K, Becker-Catania S, Coskun V, Zhu W, Wu H, Castro D, Guillemot F, Fan G, et al. A positive autoregulatory loop of Jak-STAT signaling controls the onset of astrogliogenesis. Nat Neurosci. 2005;8:616-25.

24. Beurel $E$, Jope RS. Differential regulation of STAT family members by glycogen synthase kinase-3. J Biol Chem. 2008;283:21934-44.

25. Jope RS, Yuskaitis CJ, Beurel E. Glycogen synthase kinase-3 (GSK3): inflammation, diseases, and therapeutics. Neurochem Res. 2007;32:577-95.

26. Martin M, Rehani K, Jope RS, Michalek SM. Toll-like receptor-mediated cytokine production is differentially regulated by glycogen synthase kinase 3. Nat Immunol. 2005:6:777-84

27. Kubo T, Nishimura S, Oda T. Amyloid beta-peptide alters the distribution of early endosomes and inhibits phosphorylation of Akt in the presence of 3-(4,5-dimethylthiazol-2-yl)-2,5-diphenyltetrazolium bromide (MTT). Brain Res Mol Brain Res. 2002;106:94-100.

28. Burdick D, Soreghan B, Kwon M, Kosmoski J, Knauer M, Henschen A, Yates J, Cotman C, Glabe C. Assembly and aggregation properties of synthetic Alzheimer's A4/beta amyloid peptide analogs. J Biol Chem. 1992;267:546-54.

29. Chen L, Wang H, Zhang Z, Li Z, He D, Sokabe M, Chen L. DMXB (GTS-21) ameliorates the cognitive deficits in beta amyloid(25-35(-)) injected mice through preventing the dysfunction of alpha7 nicotinic receptor. J Neurosci Res. 2010;88:1784-94.

30. Maurice T, Lockhart BP, Privat A. Amnesia induced in mice by centrally administered beta-amyloid peptides involves cholinergic dysfunction. Brain Res. 1996;706:181-93.

31. Bouter Y, Dietrich K, Wittnam JL, Rezaei-Ghaleh N, Pillot T, Papot-Couturier S, Lefebvre T, Sprenger F, Wirths O, Zweckstetter M, Bayer TA. N-truncated amyloid beta (Abeta) 4-42 forms stable aggregates and induces acute and long-lasting behavioral deficits. Acta Neuropathol. 2013;126:189-205

32. Jin H, Chen T, Li G, Wang C, Zhang B, Cao X, Sha S, Wan O, Chen L. Dose-dependent neuroprotection and neurotoxicity of simvastatin through reduction of farnesyl pyrophosphate in mice treated with intracerebroventricular injection of Abeta 1-42. J Alzheimers Dis. 2016:50:501-16

33. Sheroziya M, Timofeev I. Global intracellular slow-wave dynamics of the thalamocortical system. J Neurosci. 2014;34:8875-93.

34. Wang C, Chen T, Li G, Zhou L, Sha S, Chen L. Simvastatin prevents beta-amyloid25-35-impaired neurogenesis in hippocampal dentate gyrus through alpha7nAChR-dependent cascading PI3K-Akt and increasing BDNF via reduction of farnesyl pyrophosphate. Neuropharmacology. 2015;97:122-32.

35. Xia Y, Xia YF, Lv Q, Yue MF, Qiao SM, Yang Y, Wei ZF, Dai Y. Madecassoside ameliorates bleomycin-induced pulmonary fibrosis in mice through promoting the generation of hepatocyte growth factor via PPAR-gamma in colon. Br J Pharmacol. 2016;173:1219-35.

36. West MJ. New stereological methods for counting neurons. Neurobiol Aging. 1993;14:275-85

37. Karacay B, Mahoney J, Plume J, Bonthius DJ. Genetic absence of nNOS worsens fetal alcohol effects in mice. II: microencephaly and neuronal losses. Alcohol Clin Exp Res. 2015;39:221-31.

38. Long JM, Kalehua AN, Muth NJ, Calhoun ME, Jucker M, Hengemihle JM, Ingram DK, Mouton PR. Stereological analysis of astrocyte and microglia in aging mouse hippocampus. Neurobiol Aging. 1998;19:497-503.
39. Yang YJ, Zhang S, Ding JH, Zhou F, Hu G. Iptakalim protects against MPP +-induced degeneration of dopaminergic neurons in association with astrocyte activation. Int J Neuropsychopharmacol. 2009;12:317-27.

40. Dutuit M, Didier-Bazes M, Vergnes M, Mutin M, Conjard A, Akaoka H, Belin MF, Touret M. Specific alteration in the expression of glial fibrillary acidic protein, glutamate dehydrogenase, and glutamine synthetase in rats with genetic absence epilepsy. Glia. 2000;32:15-24

41. Tsai CC, Kai Jl, Huang WC, Wang CY, Wang Y, Chen CL, Fang YT, Lin YS, Anderson R, Chen SH, et al. Glycogen synthase kinase-3beta facilitates IFN-gamma-induced STAT1 activation by regulating Src homology-2 domain-containing phosphatase 2. J Immunol. 2009:183:856-64.

42. Esposito G, Scuderi C, Valenza M, Togna Gl, Latina V, De Filippis D, Cipriano M, Carratu MR, luvone T, Steardo L. Cannabidiol reduces Abeta-induced neuroinflammation and promotes hippocampal neurogenesis through PPARgamma involvement. PLoS One. 2011;6:e28668.

43. Landreth GE, Heneka MT. Anti-inflammatory actions of peroxisome proliferator-activated receptor gamma agonists in Alzheimer's disease. Neurobiol Aging. 2001;22:937-44

44. Park SH, Kim JH, Choi KH, Jang YJ, Bae SS, Choi BT, Shin HK. Hypercholesterolemia accelerates amyloid beta-induced cognitive deficits. Int J Mol Med. 2013;31:577-82.

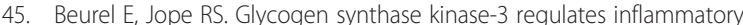
tolerance in astrocytes. Neuroscience. 2010;169:1063-70.

46. D'Angelo B, Ek CJ, Sun Y, Zhu C, Sandberg M, Mallard C. GSK3beta inhibition protects the immature brain from hypoxic-ischaemic insult via reduced STAT3 signalling. Neuropharmacology. 2016;101:13-23.

47. Beurel E, Jope RS. Lipopolysaccharide-induced interleukin-6 production is controlled by glycogen synthase kinase-3 and STAT3 in the brain. J Neuroinflammation. 2009:6:9

48. Jones DC, Ding X, Daynes RA. Nuclear receptor peroxisome proliferatoractivated receptor alpha (PPARalpha) is expressed in resting murine lymphocytes. The PPARalpha in T and B lymphocytes is both transactivation and transrepression competent. J Biol Chem. 2002:277:6838-45.

49. Liu JJ, Dai XJ, Xu Y, Liu PQ, Zhang Y, Liu XD, Fang ZG, Lin DJ, Xiao RZ, Huang RW, Huang HQ. Inhibition of lymphoma cell proliferation by peroxisomal proliferator-activated receptor-gamma ligands via Wnt signaling pathway. Cell Biochem Biophys. 2012;62:19-27.

50. Lin CF, Tsai CC, Huang WC, Wang CY, Tseng HC, Wang Y, Kai Jl, Wang SW, Cheng YL. IFN-gamma synergizes with LPS to induce nitric oxide biosynthesis through glycogen synthase kinase-3-inhibited IL-10. J Cell Biochem. 2008;105:746-55.

51. Zhao X, Strong R, Zhang J, Sun G, Tsien JZ, Cui Z, Grotta JC, Aronowski J. Neuronal PPARgamma deficiency increases susceptibility to brain damage after cerebral ischemia. J Neurosci. 2009:29:6186-95.

52. Aisen PS. The potential of anti-inflammatory drugs for the treatment of Alzheimer's disease. Lancet Neurol. 2002;1:279-84.

53. Walsh DM, Selkoe DJ. Deciphering the molecular basis of memory failure in Alzheimer's disease. Neuron. 2004:44:181-93.

54. Ito D, Fujisawa T, lida H, Suzuki N. Characterization of seipin/BSCL2, a protein associated with spastic paraplegia 17. Neurobiol Dis. 2008:31:266-77.

55. Maragakis NJ, Rothstein JD. Mechanisms of disease: astrocytes in neurodegenerative disease. Nat Clin Pract Neurol. 2006:2:679-89.

\section{Submit your next manuscript to BioMed Central and we will help you at every step:}

- We accept pre-submission inquiries

- Our selector tool helps you to find the most relevant journal

- We provide round the clock customer support

- Convenient online submission

- Thorough peer review

- Inclusion in PubMed and all major indexing services

- Maximum visibility for your research

Submit your manuscript at www.biomedcentral.com/submit 